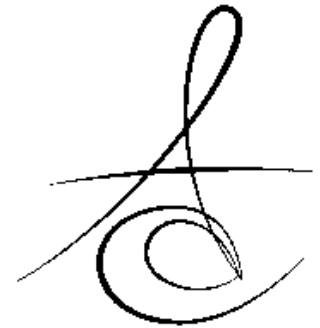

Makale Kodu/Article code: 1389

Makale Gönderilme tarihi: 06.11 .2013

Kabul Tarihi: 22.11.2013

\section{EFFECT OF SEPARATED ROTARY INSTRUMENTS ON THE APICAL MICROLEAKAGE OF ROOT CANAL FILLINGS*}

\section{KÖK KANALINDA KIRILMIŞ DÖNER ALETLERİN KÖK KANALININ APİKAL MIKROSIZINTISI ÜZERİNE ETKİSİ ${ }^{*}$}

Yrd. Doç. Dr.Evren OK*
Yrd. Doç. Dr.Hüseyin ERTAŞ**

\section{ABSTRACT}

Aim: The aim of this in vitro study was to compare the effect of separated fragments from two different nickel titanium rotary instruments on microleakage of the root canal filling.

Material and method: Extracted anterior teeth with single canal and straight roots were used. The teeth were divided into three groups. Group 1 and Group 3 (the control group) were shaped with ProTaper ${ }^{\circledR}$ rotary nickel-titanium (NiTi) files; Group 2 was shaped with Revo-S ${ }^{\circledR}$ rotary files. In Group 1, ProTaper ${ }^{\circledR}$ F3 files and in Group 2, Revo-S ${ }^{\circledR} 30 / 06$ files, were broken in the apical one-third part of the root canals. All canals were obturated with gutta-percha and AH Plus sealer. After immersion in basic fuchsine stain solutions for $48 \mathrm{~h}$, the roots were longitudinally sectioned. Digital photographs of the root sections were evaluated with image analysis software. Statistical analyses were performed with one way ANOVA and Tamhane test.

Results: Microleakage of the control group was significantly less than Group 1 and Group 2. However, there was no statistically significant difference between the microleakage values of the groups separated ProTaper ${ }^{\circledR}$ or Revo- $S^{\circledR}$ instruments.

Conclusion: Separation of rotary NiTi instruments in the root canals negatively affected the apical seal of the root canal fillings, regardless of the instrument type.

Keywords: $\quad$ ProTaper $^{\circledR}$, Revo- $S^{\circledR}$, fractured instrument, microleakage, dye leakage
ÖZET

Amaç: $\mathrm{Bu}$ in vitro çalışmanın amacı kök kanalının apikal üçlü bölgesinde kırılmış iki farklı tipteki nikel titanyum döner aletin kök kanal dolgusunun apikal mikrosızıntısı üzerine etkisinin karşılaştırılmasıdır.

Materyal ve metot: Bu çalışmada çekilmiş üst çene ön dişler kullanıldı. Kronlar uzaklaştırıldıktan sonra dişler rastgele 3 gruba ayrıldı $(n=12)$. Kontrol grubu (Grup 3) ve Grup 1 ProTaper döner aletleri ile, Grup 2 Revo-S döner aletler ile şekillendirildi. Grup 1'de Protaper F3, Grup 2'de Revo-S 30/06 döner alet kök kanalının apikal üçlü bölgesinde kırıldı. Bütün dişler lateral kondensasyon tekniği ile AH Plus ve guta-perka kullanılarak dolduruldu. 48 saat bazik fuksin solüsyonunda bekletildikten sonra dişler uzunlamasına iki eşit parçaya bölündü. Doğrusal mikrosızıntı ölçümü için kök kesitlerinin dijital fotoğrafları imaj analiz yazılımı kullanılarak değerlendirildi. İstatistiksel analizler tek yönlü ANOVA ve Tamhane testleri ile yapıldı.

Bulgular: Kontrol grubunun mikrosızıntısı kırık alet olan gruplardan anlamlı şekilde azdı. Ancak, kanal içinde ProTaper ve Revo-S eğeleri kırılan gruplar arasında istatistiksel olarak anlamlı fark yoktu $(p=0,992)$.

Sonuç: Döner NiTi kök kanal eğelerinin kök kanalı içerisinde kırıması kök kanal dolgusunun apikal mikrosızıntısını kanal eğesinin tipinden bağımsız olarak olumsuz şekilde etkiledi.

Anahtar kelimeler: ProTaper $\AA$, Revo-S $₫$, kırık alet, mikrosızıntı, boya penetrasyon

*İzmir Şifa Üniversitesi, Diş Hekimliği Fakültesi, Endodonti AD,

**̇zmir Katip Çelebi Üniversitesi, Diş Hekimliği Fakültesi, Endodonti AD,

"Bu çalışma "Ege Bölgesi Dişhekimleri Odası 16. Uluslararsı Bilimsel Kongre ve Sergisi"nde Poster olarak sunulmuştur. 


\section{INTRODUCTION}

Nickel-titanium (NiTi) rotary instruments are commonly used to prepare a tooth for a root canal procedure because $\mathrm{NiTi}$ instruments reduce operator fatigue and produce well-centered, uniform, and minimally-transported canals. ${ }^{1}$ Despite these advantages, NiTi instruments suffer from one serious disadvantage: the instruments tend to fracture during use $^{2}$. Iqbal et al. ${ }^{3}$ found that NiTi rotary instruments separated almost seven times more frequently than hand instruments. The incidence of separations in instruments that had been used multiple times previously varied from $3 \%$ to $21 \% .^{4-7}$ In addition, NiTi instruments are most likely to separate in the apical third of the mesiobuccal canals of maxillary and mandibular molars. ${ }^{6}$

The ProTaper $^{\circledR}$ Universal System (Dentsply, Tulsa, OK) consists of three shaping files and three finishing files. Of all ProTaper $®$ Universal files, the highest incidence of separation occurs while using the F3 files. ${ }^{8}$

The Revo-S ${ }^{\circledR} \mathrm{NiTi}$ instrument system includes three shaping files and three apical enlargement files. The manufacturer suggests that the Revo- $S^{\circledR}$ instruments can be used several times to prepare root canals without separating.

Separation of the instrument in the apical part of the root canal is an important factor for determining the prognosis of root canal treatment. Files that separate in the coronal and middle third of the root canal can be removed consistently without major complications, but outcome cannot be predicted for instruments that separate in the apical third of the canal $^{9}$. The difficulty in reaching the fractured instrument, the irregularity of the root canal anatomy, the degree of canal curvature and risk of perforation ${ }^{6,9}$ often make nonsurgical removal of the instrument fragments impossible.

Due to the increased flexibility and elasticity of $\mathrm{NiTi}$ instruments, removing the fragments from one when it breaks in the apical part of root canals is more difficult than removing fragments of a hand instrument if it breaks in the same region ${ }^{10}$. When the clinician attempts to remove broken-off $\mathrm{NiTi}$ instruments, the fragments have a greater tendency to fracture or sometimes may even screw themselves into the walls of the root canal. ${ }^{11}$ No more than $87 \%$ of the broken instruments can be removed completely without perforating the root ${ }^{11}$; in other words, broken $\mathrm{NiTi}$ instrument might be left in the root canal.

Some studies suggest that separated instruments may not affect healing ${ }^{6,12,13}$ if the procedure is performed to a high standard and the canal filling is hermetically sealed. ${ }^{13}$ So far, however, in literatüre there has been no study that evaluates the effect of different types of separated instruments on microleakage in apical third of root canals. The aim of this in vitro study was to compare the effect of separated two different nickel titanium rotary instruments on microleakage in the apical third of root canals.

\section{MATERIALS AND METHOD}

In the present study, 36 freshly-extracted, human, single-rooted anterior teeth with single, straight roots and mature apices were used. Preoperative radiographs ensured that the teeth did not have any root caries, fractures, multiple canals, lateral canals, calcifications or internal resorptions.

The teeth were maintained in $10 \%$ formalin solution for 24 hours and transferred to saline solution at the time of use. Clinical crowns were removed below the cementum-enamel junction, using a lowspeed diamond saw under water spray, to create a standardized root length of $12 \mathrm{~mm}$. Working length was determined with a \#15 K-file (Dentsply Maillefer, Ballaigues, Switzerland) $1.0 \mathrm{~mm}$ above the apical foramen.

\section{Root Canal Instrumentation}

All samples were randomly divided into three groups $(n=12)$ according to the type of rotary instrument to be used. All the samples were prepared using EndoGel (Henry Schein, Inc., Melville, NY) and rotary instruments powered by an endodontic micromotor X-Smart (Dentsply, Maillerfer) at a speed of 350 rpm.

Group 1 (ProTaper $^{\circledR}$ ): The root canals of 12 teeth were prepared to the working length with ProTaper $^{\circledR}$ rotary instruments (Dentsply Maillefer, Ballaigues, Switzerland) to the size of the F2 file (25/0.06), according to the manufacturer's instructions. Each canal was irrigated between each filing with $2 \mathrm{~mL}$ of $5.25 \% \mathrm{NaOCl}$, using a syringe and a 27-gauge needle to clear debris. The F3 files were 
notched $4 \mathrm{~mm}$ from the tip with a knife edge bur to facilitate separating the file at a set length. While the notched end of the file was in the apical part of the root canal, the rotary instruments were run at a hightorque level in order to make the instrument break. Then the teeth radiographed from the mesiodistal direction to check whether the separated instrument was located successfully in the apical one-third part of the root canal (Figure 1). We eliminated from the study population any specimen in which the rotary NiTi file separated at a improper level of the root canal or the broken fragments were found beyond the apical foramen, and prepared a new specimen to replace it.

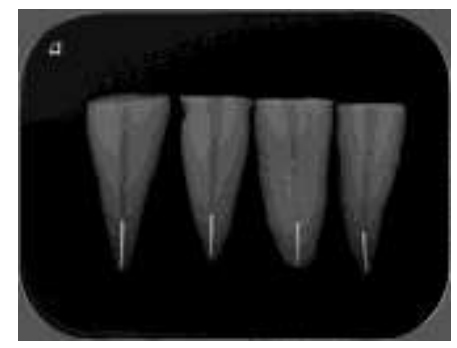

Figure 1 . A radiographic view of apically separated files.

Group 2 (Revo-S $\left.{ }^{\circledR}\right)$ : The root canals of 12 teeth were prepared to the working length with Revo- $S^{\circledR}$ rotary instruments (Micro-Mega, Besançon, France) to a size of 25/0.06, according to the manufacturer's instructions. Each canal was irrigated between each filing with $2 \mathrm{~mL}$ of $5.25 \% \mathrm{NaOCl}$, using a syringe and a 27-gauge needle to clear debris. The Revo- $\mathrm{S}^{\mathrm{TM}}$ 30/0.06 rotary files were notched with a knife edge bur $4 \mathrm{~mm}$ from the tip. In the same manner as for Group 1, the Revo-S ${ }^{\circledR}$ files were run in the root canal until they broke. The teeth in Group 2 were then radiographed from a mesiodistal direction. We discarded any specimens where the file fragments failed to lodge in the apical one-third of the root canal and prepared substitute specimens, as in Group 1.

Group 3 (Control): Twelve teeth were used as control. Root canals were prepared to the working length with ProTaper $^{\circledR}$ rotary instruments (Dentsply Maillefer, Ballaigues, Switzerland) to the size of the F3 file (30/0.06), according to the manufacturer's recommendation. Each canal was irrigated with $2 \mathrm{~mL}$ $5.25 \% \mathrm{NaOCl}$ between each filing to clear debris, using a syringe and a 27-gauge needle.

\section{Root Canal Filling}

All of the root canals were obturated with gutta-percha and AH Plus sealer (Dentsply Maillefer) using a lateral condensation technique and excess gutta-percha was removed with a hot instrument and condensed vertically. After obturation, radiographs were taken from all groups to check the condensation of root canal filings (Figure 2).

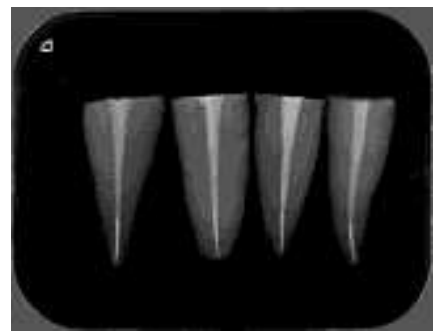

Figure 2. A radiographic view of final root canal fillings.

\section{Apical Dye Leakage}

After obturation, all roots were coated with a double layer of nail varnish and sticky wax except the apical $1 \mathrm{~mm}$, which were left uncovered. The specimens were placed in basic fuchsin stain solution for $48 \mathrm{~h}$. After immersion in the basic fuchsin solution, the specimens were washed under tap water for $1 \mathrm{~h}$ and dried with compressed air.

The teeth were then sectioned longitudinally from the buccal-lingual direction using a diamond disc without damaging the root canal filling (Figure 3). Digital photographs were taken of all the sections of roots. Marginal leakage of fuchsin dye (Figure 4) was evaluated with AutoCAD and Photoshop image analysis software.

\section{Statistics}

The statistical significance of the differences was determined using one way ANOVA and Tamhane test (SPSS Version 16.0).

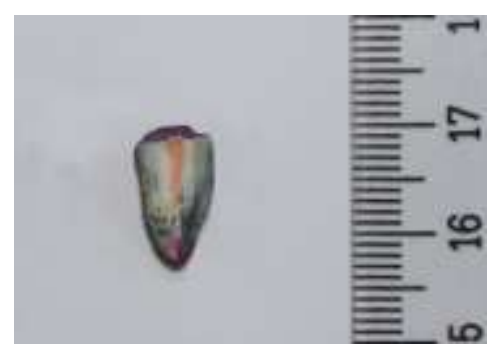

Figure 3. An example of sectioned root. 


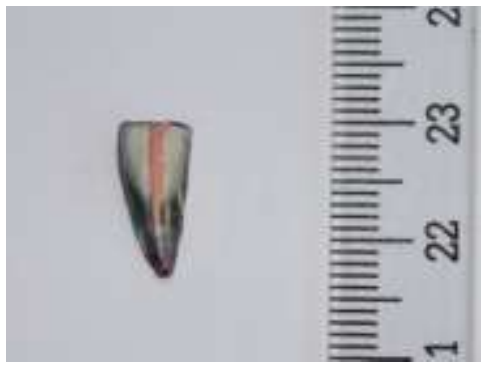

Figure 4. An example of dye leaked separated file.

\section{RESULTS}

Microleakage of the negative control group of teeth was significantly less than the microleakage we found in groups 1 and $2(p<0.001)$. However, there were no statistically significant differences between the microleakage values of teeth containing separated fragments of ProTaper $^{\circledR}$ or Revo- $S^{\circledR}$ instruments $(\mathrm{p}=0.992)$ (Table 1).

Table 1. Effect of separated file on the dye microleakage of obturated teeth.

\begin{tabular}{|l|c|c|c|c|}
\hline Groups & Mean $(\mathrm{mm})$ & $\mathrm{n}$ & $\begin{array}{c}\text { Std. } \\
\text { Deviation }\end{array}$ & $\begin{array}{c}\text { Std. Error of } \\
\text { the Mean }\end{array}$ \\
\hline Negative & $1,17^{\mathrm{a}}$ & 12 & 0,58205 & 0,16802 \\
Control & $2,85^{\mathrm{b}}$ & 12 & 1,13258 & 0,32695 \\
ProTaper & $2,97^{\mathrm{b}}$ & 12 & 1,29694 & 0,37439 \\
Revo S & \multicolumn{3}{|l}{} \\
\hline
\end{tabular}

(There was no significant difference between the groups with same letters; $p>0.05$ ).

\section{DISCUSSION}

According to the results of our present study, separation of a NiTi rotary instrument increased the microleakage of root canal filling approximately threefold, compared to the negative control group. Fracture of endodontic files is an unpleasant but common incident during preparation of a root canal. ${ }^{14}$ The fragments prevent efficient cleaning and shaping of the root canal and may result in a poor prognosis. ${ }^{15}$ Nonetheless, the separation of $\mathrm{NiTi}$ instruments remains a problem that may occur in an unpredictable way. ${ }^{4,16}$ Two distinct mechanisms have been reported by which fracture of a NiTi instrument may occur. One is torsional failure ${ }^{14,17}$, the other is cyclic fatigue fracture. ${ }^{14,17,18}$

If a root canal treatment is completed to high standards, but without removing the NiTi fragments successfully, the retained file fragments may hinder control of microbial growth in the root canal beyond the obstruction. ${ }^{6}$ In the event an endodontic file fractures, the best solution is to remove the fragment without complications. ${ }^{19}$ Fors and Berg, ${ }^{20}$ however, recommended leaving fragments from fractured instruments in place if they are resting in the apical one-third of the root canal, because retrieval attempts can perforate the root, diminishing the prognosis of successful root canal treatment.

Ultrasonics has been reported as the most frequently-used technique for retrieving fractured instruments. ${ }^{21}$ Even though a number of studies have reported relatively good success rates using this technique, complications still may occur. ${ }^{9-11,22,23} \mathrm{~A}$ survey concluded by Madarati at al. showed that $61.8 \%$ of dentists had experienced complications during or after retrieval of separated root canal instruments. ${ }^{21}$

The roots which tightened $15 \mathrm{~K}$-file (Dentsply Maillefer, Ballaigues, Switzerland) at apex used in this study were selected from central incisors because the anatomical structure of these roots was liable to produce more-standardized results.

ProTaper $^{\circledR}$ F3 rotary files were used in this study, since F3 files experience the highest incidence of instrument separations among all ProTaper $^{\circledR}$ Universal files. ${ }^{8}$ Saunders at al. ${ }^{24}$ determined the length of the separated instrument fragment in their study to be $3 \mathrm{~mm}$. While in the present study, we set this length at $4 \mathrm{~mm}$. We chose this longer fragment because we wanted to compare the effect of different rotary instruments; if the linear microleakage reached or extended as far as $3 \mathrm{~mm}$, the $4 \mathrm{~mm}$ broken file fragment provides more area from which to measure healthy linear die leakage.

Saunders et al. ${ }^{24}$, Torabinejad et al. ${ }^{25}$ and Khayat et al. ${ }^{26}$ reported substantial distances when investigating how far bacteria penetrate through root canal fillings. These authors reported that the dye molecules were able to penetrate into areas that might not be reached by bacteria. ${ }^{27,28}$ In other words, dye is considered to be a more sensitive tracer than bacterial or bacteria-sized tracers. ${ }^{27,28}$ 
Saunders et al. ${ }^{24}$ reported that the presence of a $3 \mathrm{~mm}$ fragment of a NiTi instrument did not speed up or slow down penetration of bacteria, when compared with the normally obturated experimental group, and concluded that the broken file fragment did not compromise obturation, of the root canal space. Altundaser at al. ${ }^{29}$ reported that significantly less microleakage was seen in the presence of separated ProTaper ${ }^{\circledR}$ instruments than in root canal prepared by non-fractured versions of those tools. In the present study, roots with the retained NiTi rotary file fragments showed significantly greater leakage than those filled without separated fragments, whereas there was no significant difference in the microleakage between the ProTaper ${ }^{\circledR}$ and Revo $S^{\circledR}$ fragments. The differences in the design of these two commercial systems did not affect the amount of microleakage significantly. The cause of three different results of these studies could be that three different methods were used to evaluate the leakage. On the other hand, notching the rotary files to induce the break and separation to occur within the apical onethird of the root canal might lead to an unrealistically low rate of retaining the separated segments which could decrease debris accumulation in the grooves of the file and have caused more leakage.

\section{CONCLUSION}

In the limitations of this in vitro study, separation of the rotary NiTi root canal instruments negatively affected the apical seal of the root canal filling, regardless of the differences in the crosssectional design of the types of instrument. The results of this study point out that the broken fragments of the instruments themselves play an important role in sealing the root canal treatments, potentially leading to an unpredictable clinical prognosis.

Conflict of interest: All authors declare that that they have no conflict of interest.

\section{REFERENCES}

1. Hubscher W, Barbakow F, Peters OA. Root-canal preparation with FlexMaster: canal shapes analysed by micro-computed tomography. Int Endod J 2003;36:740-7.
2. Ruddle $\mathrm{CJ}$. Nonsurgical endodontic retreatment. J Calif Dent Assoc 2004;32:474-84.

3. Iqbal MK, Kohli MR, Kim JS. A retrospective clinical study of incidence of root canal instrument separation in an endodontics graduate program: a PennEndo database study. J Endod 2006;32:104852.

4. Parashos $\mathrm{P}$, Messer $\mathrm{HH}$. Rotary NiTi instrument fracture and its consequences. J Endod 2006;32:1031-43.

5. Al-Fouzan KS. Incidence of rotary ProFile instrument fracture and the potential for bypassing in vivo. Int Endod J 2003;36:864-7.

6. Spili $\mathrm{P}$, Parashos $\mathrm{P}$, Messer $\mathrm{HH}$. The impact of instrument fracture on outcome of endodontic treatment. J Endod 2005;31:845-50.

7. Alapati SB, Brantley WA, Svec TA, et al. SEM observations of nickel-titanium rotary endodontic instruments that fractured during clinical use. J Endod 2005;31:40-3.

8. Wu J, Lei $G$, Yan $M$, et al. Instrument separation analysis of multi-used ProTaper Universal rotary system during root canal therapy. J Endod 2011;37:758-63.

9. Souter NJ, Messer HH. Complications associated with fractured file removal using an ultrasonic technique. J Endod 2005;31:450-2.

10. Ward JR, Parashos P, Messer HH. Evaluation of an ultrasonic technique to remove fractured rotary nickel-titanium endodontic instruments from root canals: an experimental study. J Endod 2003; 29:756-63.

11. Suter B, Lussi A, Sequeira P. Probability of removing fractured instruments from root canals. Int Endod J 2005;38:112-23.

12. Ingle JI, Glick D. The Washington study. In: Ingle JI, editor. Endodontics. 1 ed. Philadelphia: Lea and Febiger; 1965.54

13. Crump MC, Natkin E. Relationship of broken root canal instruments to endodontic case prognosis: a clinical investigation. J Am Dent Assoc 1970;80:1341-7.

14. Madarati AA, Watts DC, Qualtrough AJ. Opinions and attitudes of endodontists and general dental practitioners in the UK towards the intracanal fracture of endodontic instruments: part 1. Int Endod J 2008;41:693-701. 
15. Lin LM, Rosenberg PA, Lin J. Do procedural errors cause endodontic treatment failure? J Am Dent Assoc 2005;136:187-93; quiz 231.

16. Hulsmann $M$, Schinkel I. Influence of several factors on the success or failure of removal of fractured instruments from the root canal. Endod Dent Traumato. 1999;15:252-8.

17. Peters OA, Peters CI, Schonenberger K, Barbakow F. ProTaper rotary root canal preparation: effects of canal anatomy on final shape analysed by micro CT. Int Endod J 2003;36:86-92.

18. Roland DD, Andelin WE, Browning DF, Hsu GH, Torabinejad $M$. The effect of preflaring on the rates of separation for 0.04 taper nickel titanium rotary instruments. J Endod 2002;28:543-5.

19. Madarati AA, Qualtrough AJ, Watts DC. A microcomputed tomography scanning study of root canal space: changes after the ultrasonic removal of fractured files. J Endod 2009;35:125-8.

20. Fors UG, Berg JO. Endodontic treatment of root canals obstructed by foreign objects. Int Endod J 1986;19:2-10.

21. Madarati A, Watts DC, Qualtrough AE. A survey on the experience of UK endodontists and general practitioners in the management of intracanal fractured files. Int Endod J 2008;41:816.

22. Shen Y, Peng B, Cheung GS. Factors associated with the removal of fractured $\mathrm{NiTi}$ instruments from root canal systems. Oral Surg Oral Med Oral Pathol Oral Radiol Endod 2004;98:605-10.

23. Çiçek $E$, Bodrumlu E. Ultrasonics in endodontics: a review. J Dent Fac Atatürk Uni 2012;6:76-83.

24. Saunders JL, Eleazer PD. Effect of a separated instrument on bacterial penetration of obturated root canals. J Endod 2004;30:177-179.

25. Torabinejad $M$, Ung $B$, Kettering JD. In vitro bacterial penetration of coronally unsealed endodontically treated teeth. J Endod 1990;16:566-9.

26. Khayat A, Lee SJ, Torabinejad M. Human saliva penetration of coronally unsealed obturated root canals. J Endod 1993;19:458-61.

27. Barthel CR, Moshonov J, Shuping G, Orstavik D. Bacterial leakage versus dye leakage in obturated root canals. Int Endod J 1999;32:370-5.

28. Kersten HW, Moorer WR. Particles and molecules in endodontic leakage. Int Endod J 1989;22:11824.
29. Altundasar E, Sahin C, Ozcelik B, Cehreli ZC. Sealing properties of different obturation systems applied over apically fractured rotary nickeltitanium files. J Endod 2008;34:194-7.

\section{Yazışma Adresi:}

Evren OK, PhD, DDS

Assistant Professor and Chair, Department of Endodontics, Faculty of Dentistry, Şifa University, Izmir, Turkey

Tel: +90-232- 3434445 /1725, 05065581678

Fax: +90-232- 3435656

E-mail: dh.evrenok@hotmail.com, evren.ok@sifa.edu.tr 